\title{
外側型腰椎椎間板ヘルニアの治療成績
}

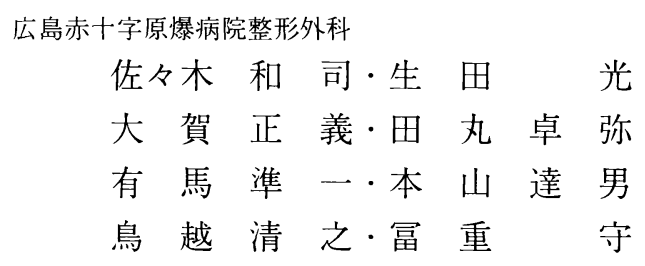

\section{Clinical Study of Lateral Lumbar Disc Herniation}

\author{
Kazushi Sasaki, Kou Ikuta, Masayoshi Oga, \\ Takuya Tamaru, Junichi Arima, Tatsuo Motoyama, \\ Kiyoyuki Torigoe and Mamoru Tomishige \\ Department of Orthopaedic Surgery, \\ Hiroshima Red Cross and Atomic-Bomb Survivous Hospital
}

26 cases with lateral lumbar disc herniation were surgically treated. Of these, 18 were male and 8 were female ranging in age from 19 to 77 years old (mean; 53.2 years old). The level of lateral lumbar disc herniation was L3/4 in $7, \mathrm{~L} 4 / 5$ in 13 , and L5/S1 in 6 cases. All patients complained of severe pain in the lower extremities. Facetectomy with posterolateral fusion was performed in 9 cases, osteoplastic hemilaminectomy in 13 cases, and lateral fenestration in 4 cases (disc herniation was removed in all).

The results were as follows. The mean JOA score was 12.9/15 in the last follow-up, compared to $5.6 / 15$ pre-operatively. Excellent and good results were achieved in all cases.

Key words: Lateral lumbar disc herniation (外側型腰椎椎間板ヘルニア), osteoplastic hemilaminectomy (骨形成的偏側椎弓切除術), lateral fenestration (外側開空術), surgical treatment (手術的治療)

\section{はじめに}

$\mathrm{CT}, \mathrm{MRI}$ などの画像診断の進歩に伴い外側型腰 椎椎間板ヘルニアの診断および治療についての報告が 散見される.今回我々は, ヘルニア塊の主要部分が椎 弓根内側縁よりも外側に位置し，椎間板と同レベルの 椎間孔より出る神経根を障害する椎間孔内・外のヘル ニアを外側型腰椎椎間板ヘルニアと定義し, 手術的治 療を施行した症例についての検討を行った。

\section{対象および方法}

外側型腰椎椎間板ヘルニア手術症例 26 例を対象と した。性別は男性 18 例，女性 8 例で手術時年齢は 19 77 歳, 平均 53.2 歳であった。手術高位は L $3 / 4$ : 7 例, L4 $45: 13$ 例, L5/S1: 6 例であり, 施行した手 術法は椎間関節切除十固定術 9 例, 骨形成的偏側椎弓 切除術 13 例, 外側開空術が 4 例, 術後経過観察期間 は 1 カ月 11 年, 平均 1 年 8 カ月であった.

ヘルニアの脱出形態と施行術式，JOA score に上 る術後成績 (術式別の術後成績), 最も施行例の多い 
骨形成的偏側椎弓切除術の術後還納骨骨癒合度につい て検討を加え，各術式の特徴と術式選択の適応につい て考察した。

$$
\text { 結果 }
$$

画像求よび術中所見より外側へルニアの脱出形態を 5 typeに分類した（図 1). 26 症例中 type 1:4 例, type $2: 13$ 例, type $3: 5$ 例, type $4: 3$ 例, type $5: 1$ 例であり, 外側より脱出し椎間孔内外を上方へ 突出した type 2 が $50 \%$ と最も多かった。施行術式 は平成 6 年までは椎間関節切除十固定術を主に施行し た。平成 7 年以降は骨形成的偏側椎弓切除術を中心に 3 術式を症例に応じて施行されていた。また術式とへ ルニア形態を検討してみると, 椎間関節切除十固定術 と骨形成的偏側椎弓切除術は全ての type のヘルニア に施行していたが，外側開空術は主にへルニア塊が椎 間孔外に限局したtype 2 に行っていた（表 1$)$.

術後成績はJOA scoreの自覚症状，他覚症状のみ
の 15 点満点で評価した. 術前平均 5.6 点が術後平均 12.9 点と著明に改善していた。平林法による改善率 では $75 \%$ 以上： 18 例， $50 \%$ 以上 $75 \%$ 未満：8例と 改善率 $50 \%$ 未満の症例は 1 例もなく, 全例良好な成 績が得られていた。また術式別の術後成績は，3術式 の平均術後観察期間に違いはあるものの, 最終調査時 での改善率は全例良好で, 各術式の短期的成績に有意 差はないと思われた。

骨形成的偏側椎弓切除術施行例の還納骨の骨癒合を 単純レ線にて経時的に観察した。棘突起部は術後 6 週 で 12 例中 7 例 $(58.3 \%)$ ，術後 1 年で 7 例中 6 例 （85.7\%）に骨癒合を認め，比較的早期より骨癒合が 認められた。これに対し関節突起間部では術後早期に は骨癒合は認められなかったが, 術後 1 年では 7 例中 5 例 $(71.4 \%)$ に骨癒合が認められた。また術後 1 年 で椎間関節に明らかな関節症性変化を認めた症例は無 かった。

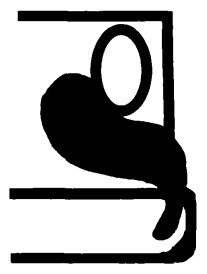

type 1
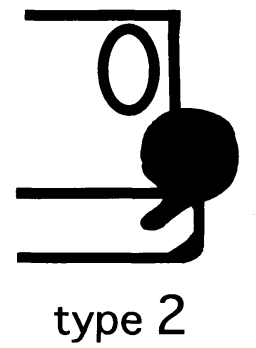

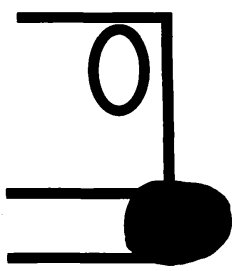

type 3

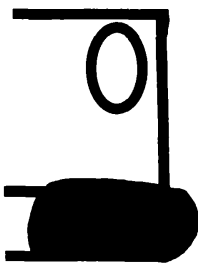

type 4

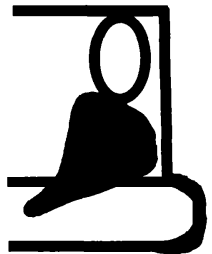

type 5

図 1 ヘルニアの脱出形態

type $1:$ 外側から脱出し春柱管内, 上方へ突出したもの

type $2:$ 椎間孔内外の上方へ突出したもの

type 3 : 椎間孔外, 椎間板レベルにヘルニア塊を認めるもの

type 4 : 偏側脊柱管内外に椎間板の膨隆を認めるもの

type 5 : 中央から椎間孔を上外側へ脱出したもの

表 1 術式とヘルニア形態

\begin{tabular}{c|ccccc|c}
\hline & type 1 & type 2 & type 3 & type 4 & type 5 & 計 \\
\hline $\mathrm{A}$ & 1 & 5 & 2 & & 1 & 9 \\
\hline $\mathrm{B}$ & 3 & 6 & 3 & 1 & & 13 \\
\hline $\mathrm{C}$ & & 2 & & 2 & & 4 \\
\hline 計 & 4 & 13 & 5 & 3 & 1 & \\
\hline
\end{tabular}

A : 椎間関節切除+固定術

B : 骨形成的偏側椎弓切除術

$\mathrm{C}:$ 外側開空術 


\section{症 例 供 覧}

症例 1,55 歳男性. 腰痛左下肢痛を主訴に来院．筋 力低下 $(-)$, 左下肢 L3 領域の知覚低下を軽度認め た。脊髄造影, CTM でL3/4レベルで左から硬膜圧 迫所見があり，CTDでは左外側から脱出したへルニ
アが春柱管内にまで突出する所見を認めた，MRIで も外側から脱出したヘルニア塊が脊柱管内に大きく migrateしている所見が認められた。この症例に対 し骨形成的偏側椎弓切除術を施行。術中左 L3 神経根 のヘルニア塊と椎弓根での圧迫を認めた。脱出形態は type 1 であった。術前 JOA： 6 点が術後 1 年で 11
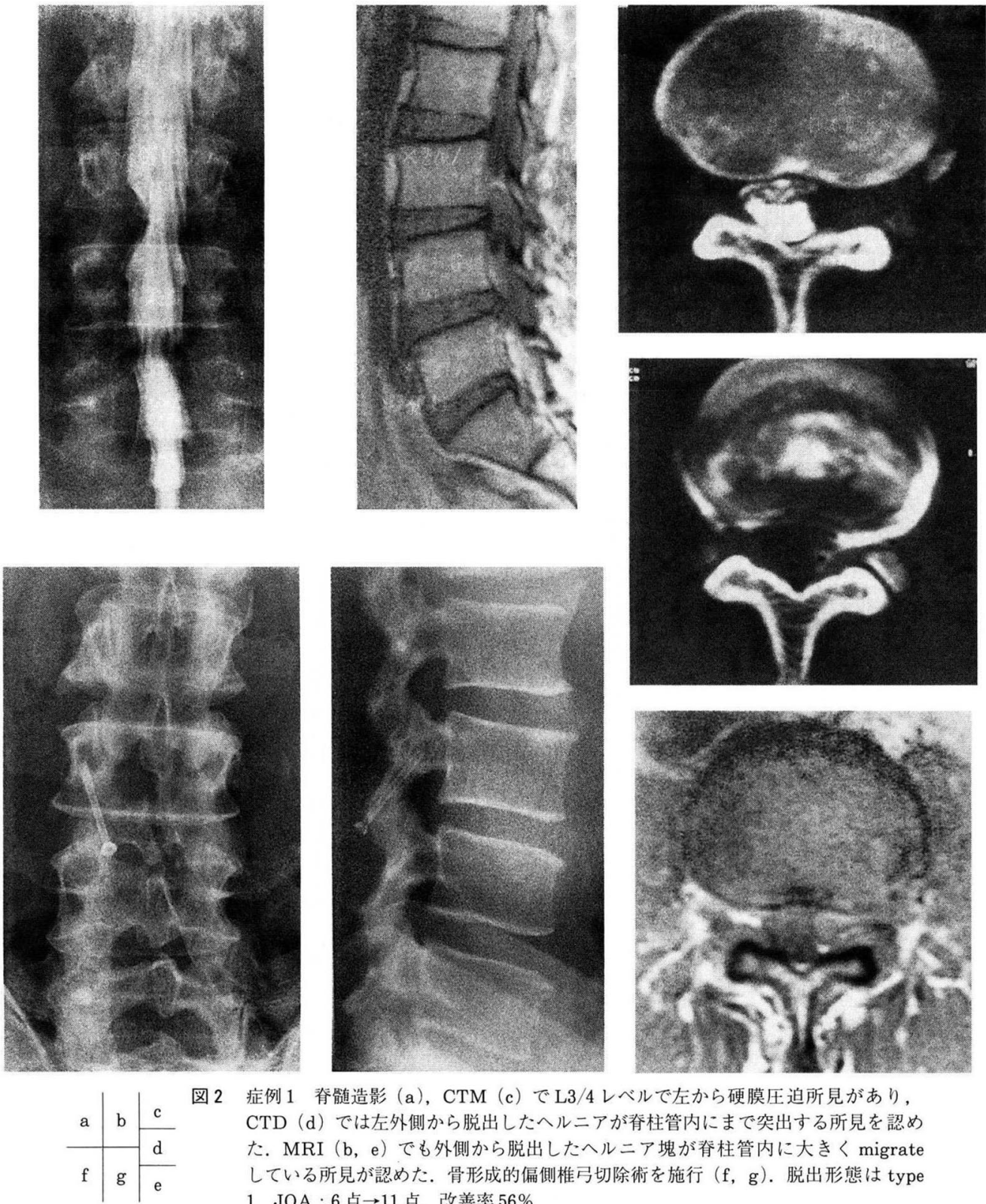

図 2 症例 1 脊髄造影（a），CTM（c）でL3/4 レベルで左から硬膜圧迫所見があり， CTD（d）では左外側から脱出したヘルニアが金柱管内にまで突出する所見を認め た. MRI（b，e）でも外側から脱出したへルニア塊が脊柱管内に大きく migrate している所見が認めた，骨形成的偏側椎弓切除術を施行 (f, g). 脱出形態は type 1 , JOA : 6 点 $\rightarrow 11$ 点, 改善率 $56 \%$ 

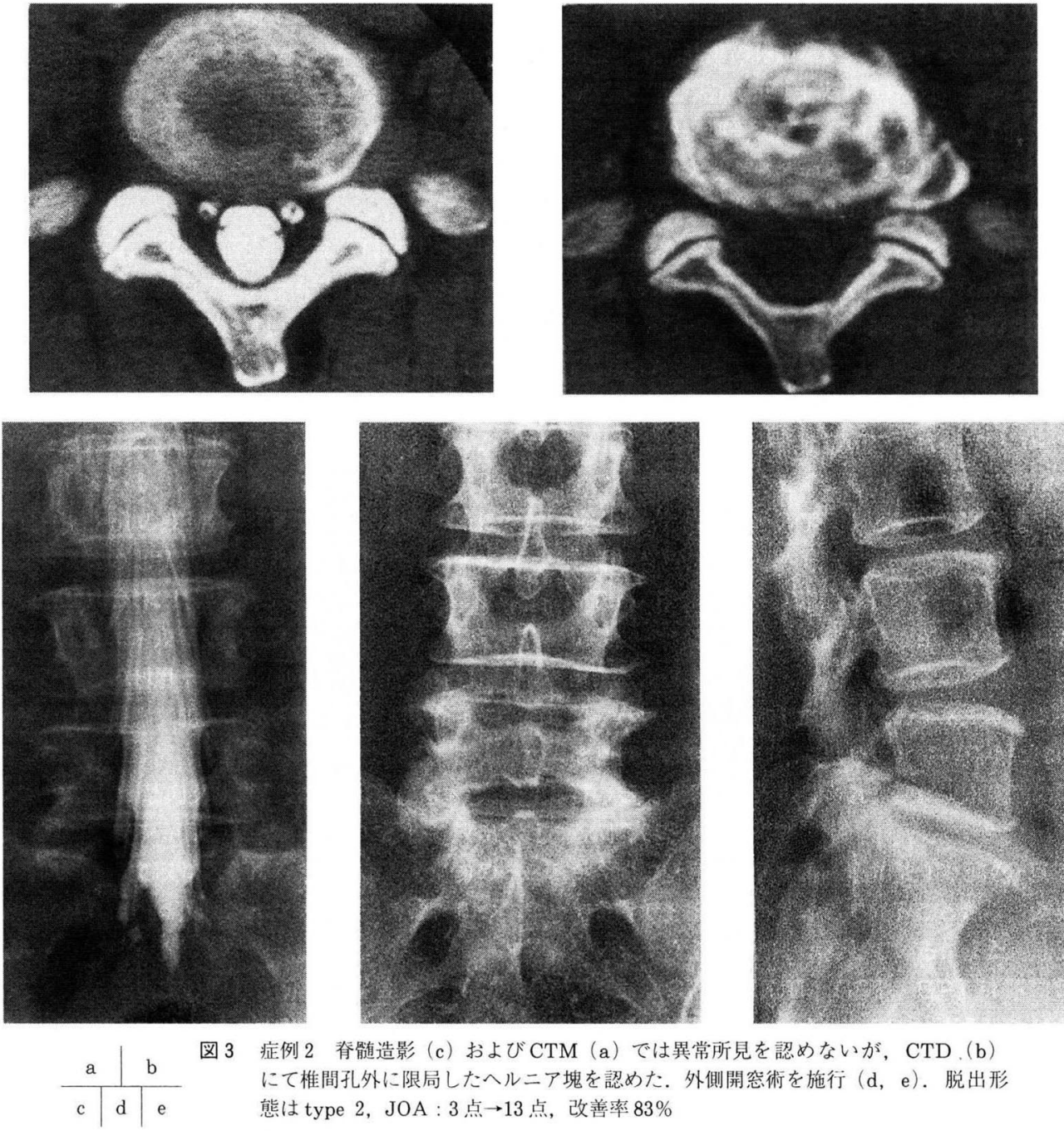

図 3 症例 2 脊䯣造影（c）および CTM（a）では異常所見を認めないが，CTD（b ) にて椎間孔外に限局したへルニア塊を認めた。外側開空術を施行 (d, e ). 脱出形 態は type 2, JOA : 3 点 $\rightarrow 13$ 点, 改善率 $83 \%$

点と改善，改善率 $56 \%$ であった（図 2).

症例 2, 64 歳女性. 腰痛と左下肢の痛み・しびれ感 を主訴に来院，脊髄造影および CTM では異常所見を 認めないが，CTDにて椎間孔外に限局したヘルニア 塊を認めた。この症例に対して, 外側開空術を施行. 術中，ヘルニアによる左 L5神経根の椎間孔外に限局 する後方への圧迫を認めた。ヘルニア脱出形態は type 2 であった. 術前 JOA : 3 点が術後 : 13 点と改 善, 改善率 $83 \%$ であった（図 3 ).
考察

外側型腰椎椎間板へルニアに対する外科的治療法 ${ }^{11}$ は様々であり, 各手術法はそれぞれ様々な利点欠点を 持つ. 椎間関節切除十固定術は固定法の問題や長期的 には固定椎上下の隣接椎間への影響が問題となる。骨 形成的偏側椎弓切除術) は術野の展開は良好であり, 安全かつ確実な除圧が可能であるが還納骨の骨癒合と, 椎間関節への影響が問題である．外側開空術 ${ }^{3)}$ は侵襲 が少なく早期の社会復帰が可能であるが, 術野のオリ エンテーションが付け難く, 術中操作が難しいという 


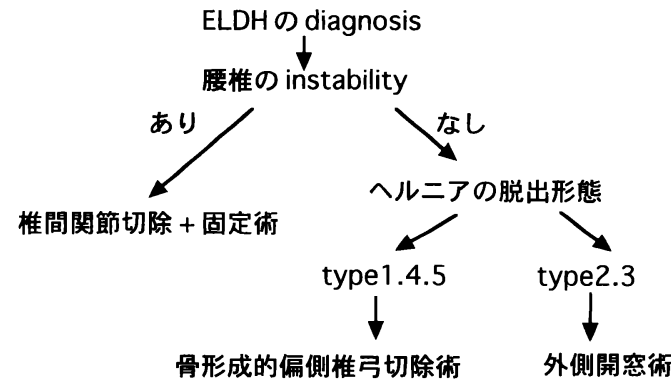

図 4 術式選択のチャート

問題点があり，更には固定術を併用した症例の方が成 績が良好であった等の報告 ${ }^{2)}$ 見受けられる。

当科では各術式の利点を考慮し, 現在では, 罹患椎 間の不安定性を認める症例では椎間関節切除＋固定術 を, 椎間孔狭窄合併例や椎間孔内外に跨るへルニア type 1，4，5に対しては骨形成的椎弓切除術を, 椎 間孔外に限局した type 2,3 には外側開密術を施行し ており（図 4)，短期ながら良好な成績が得られてい る.しかし, その中・長期成績は未明であり, 今後更 なる検討が必要と考えている。

\section{ま と め}

(1)外側型腰椎椎間板ヘルニア手術症例 26 例につい て検討した

(2)施行した術式は椎間関節切除に固定術を併用した もの 9 例, 骨形成的偏側椎弓切除術 13 例, 外側開空 術 4 例であり，全例良好な成績が得られていた。

(3)外側型腰椎椎間板ヘルニアの分類を示し各術式の 特徴と当科における術式選択のプロトコールを概説し た。

\section{参 考 文 献}

1) 藤谷正紀他：Extraforaminal lateral lumbar disc herniation一診断と手術法に関する考察一. 臨整外, 21 : 3-11, 1986.

2）森山明夫他：腰部外側ヘルニアに対しての外側開空法 によるへルニア摘出術．整・災外，33：1137-1143, 1990.

3）森山明夫他: 腰部外側神経根障害に対する外側開空術 への固定術併用について. 臨整外, 29 : 699-706, 1994.

4）小田裕㳙他：Extraforaminal lumbar disc herniation に対する骨形成的偏側椎弓切除術. 臨整外, $28: 365-73$, 1993. 